\title{
PEMBERDAYAAN KELOMPOK MELALUI INTRODUKSI RUMPUT DWARF PADA KELOMPOK USAHA BERSAMA DESA RANOTONGKOR TIMUR
}

\author{
Sintya J.K. Umboh, Hendrik O. Gijoh, Ingriet D. R. Lumentah, \\ Lidya S. Kalangi, dan Stanly O.B. Lombogia \\ Fakultas Peternakan Universitas Sam Ratulangi \\ Email: sintyajkumboh@yahoo.co.id
}

\begin{abstract}
ABSTRAK
Pembangunan peternakan memprioritaskan pada peningkatan produksi yang optimal. Salah satu usaha pendukung dalam mencapai tujuan ini yakni dengan peningkatan kualitas dan kuantitas pakan. Masalah klasik dalam budidaya ternak sapi di Desa Ranotongkor Timur adalah kekurangan pakan pada musim kemarau baik kualitas, kontinuitas, maupun kuantitas. Kondisi ini mengakibatkan ternak mengalami kehilangan bobot badan atau kematian anak sapi (pedet) umur <1tahun. Walaupun pakan tersedia sepanjang tahun, namun jumlah dan jenis pakan masih terbatas. Pakan yang dikonsumsi berupa rumput yang tumbuh liar dan limbah pertanian seperti halnya jerami jagung yang terdiri atas daun, batang, dan daun tongkol. Anggota kelompok menanam jagung dan sebagian dari tanaman jagung yang telah berbuah (jagung muda) dipotong dan diberikan kepada ternak sapi. Hal ini dilakukan petani peternak untuk mengurangi biaya pakan. Introduksi rumput dwarf dilakukan sebagai upaya untuk perbaikan kualitas dan kuantitas pakan ternak sapi serta pemanfaatan lahan tidur. Kegiatan penanaman rumput pada lahan percontohan diawali dengan kegiatan penyuluhan mengenai manfaat pengembangan rumput berkualitas untuk meningkatkan penyediaan pakan. Pemberdayaan kelompok ternak sapi Usaha Bersama melalui introduksi rumput dwarf menambah dan memperkaya jenis hijauan pakan ternak dalam upaya perbaikan kualitas pakan. Kesimpulannya, pakan yang cukup dan mempunyai nilai nutrisi tinggi merupakan salah satu faktor penting dalam upaya peningkatan produktivitas ternak sapi di Desa Ranotongkor Timur.
\end{abstract}

\section{Kata kunci: kualitas pakan, introduksi, rumput dwarf, kelompok usaha bersama}

\section{PENDAHULUAN}

Pembangunan pertanian merupakan upaya pemerintah untuk membantu petani meningkatkan produktivitas pertanian agar pendapatan dan kesejahteraan petani meningkat. Peningkatan produktivitas selain dipengaruhi oleh faktor internal dan eksternal petani juga dipengaruhi oleh peran serta kelompok tani. Kelompok tani adalah sejumlah petani dalam satu wilayah yang dibentuk atas dasar kesamaan kepentingan. Secara filosofis kelompok tani dibentuk untuk memecahkan permasalahan yang tidak dapat diatasi secara individu. Keberadaan lembaga berbasis masyarakat ini memiliki peranan penting dalam mendistribusikan program bantuan, membentuk perubahan perilaku anggotanya, dan menjalin kemampuan kerjasama antar anggota sehingga mampu memiliki wawasan, pengertian, pemikiran minat, tekad, dan kemampuan perilaku berinovasi (Nuryanti dan Swastika 2011).

Salah satu lembaga berbasis masyarakat di Provinsi Sulawesi Utara yakni Kelompok Usaha Bersama yang berada di desa Ranotongkor Timur Kecamatan Tombariri Timur. Kelompok tani yang dibentuk tahun 2012 bertujuan untuk meningkatkan pendapatan dan kesejahteraan anggota melalui upaya peningkatan produktivitas ternak sapi dan tanaman jagung sebagai usaha produktif. Mengingat kedua jenis usaha ini merupakan usaha pertanian yang sudah turun-temurun menjadi andalan usaha pertanian masyarakat.

Ditinjau dari topografi wilayah, lokasi kelompok tani berada pada ketinggian 150 meter di atas permukaan laut (BPS Sulut, 2014). Kondisi tersebut sangat sesuai dengan kondisi lingkungan yang optimal untuk tanaman jagung dan usaha ternak sapi. Kelompok tani ini beranggotakan petani peternak yang memiliki usahatani jagung dan usaha ternak sapi yang melakukan pekerjaan olah lahan tanam, menyiang, memupuk, memanen, dan beternak sapi dengan cara mapalus. Kegiatan kelompok dibuat dalam suatu rencana usahatani kelompok yang dibicarakan dalam setiap pertemuan kelompok dua kali dalam sebulan.

Beternak sapi yang dilakukan oleh anggota kelompok masih secara tradisional, belum dikandangkan, dan hanya dibiarkan di lahan pertanian. Pakan yang dikonsumsi berupa rumput yang tumbuh liar dan limbah pertanian seperti halnya jerami jagung yang terdiri atas daun, batang, dan daun tongkol. Anggota kelompok menanam jagung dan sebagian dari tanaman jagung yang telah berbuah (jagung 
muda) dipotong dan diberikan kepada ternak sapi. Hal ini dilakukan petani peternak untuk mengurangi biaya pakan karena mahalnya harga dedak dan bungkil. Hal ini sejalan dengan hasil penelitian Elly et al. (2013) bahwa 20-25\% jagung yang ditanam diberikan kepada ternak sapi. Selain itu anggota kelompok masih diperhadapkan pada persoalan ketersediaan pakan pada saat musim kemarau, dimana anggota kelompok harus mencari rumput di lahan pertanian yang jauh bahkan harus membeli dedak dan bungkil untuk memenuhi kebutuhan pakan ternak sapi.

Keberadaan Kelompok Usaha Bersama sudah berjalan dengan baik sejak dibentuk pada tahun 2012. Namun demikian tujuan dibentuknya kelompok tani untuk meningkatkan kesejahteraan petani peternak anggota belum sepenuhnya tercapai. Kondisi ini mengindikasikan bahwa keberadaan Kelompok Usaha Bersama sebagai lembaga pemberdayaan masyarakat belum berfungsi sebagaimana mestinya. Hal ini disebabkan karena belum maksimalnya antusias dan keterampilan anggota kelompok dalam merespon dan mengelola program pemerintah melalui peningkatan nilai tambah yang berdampak pada rendahnya kinerja kelompok. Padahal kelompok tani akan berhasil menjalankan perannya apabila dapat memaksimalkan fasilitas yang disediakan pemerintah maupun milik sendiri. Oleh karena itu diperlukan pendampingan dari Perguruan Tinggi sebagai pengungkit dalam meningkatkan potensi yang mempercepat dan memperkuat adopsi teknologi secara berkelanjutan oleh kelompok tani.

Masalah yang dihadapi dalam pengembangan ternak sapi adalah pakan hijauan yang tidak tersedia. Ternak sapi hanya diberikan rumput lapangan dan limbah pertanian untuk memenuhi kebutuhan pakan hijauan atau digembalakan di lahan perkebunan atau lahan yang kering lainnya dan dibiarkan mengkonsumsi rumput yang tumbuh liar. Standar kebutuhan hijauan makanan ternak per ekor per hari berdasarkan Satuan Ternak Sapi adalah ternak dewasa (1 ST) memerlukan pakan hijauan sebanyak $35 \mathrm{~kg}$, ternak muda (0.50 ST) sebanyak 15-17.5 kg dan anak ternak (0.25 ST) sebanyak 7.5-9 kg/ekor/hari. Untuk memenuhi kebutuhan ini maka anggota kelompok harus menyiapkan lahan hijauan makanan ternak (Elly et al., 2013), Polakitan dan Kairupan (2015).

Permasalahan yang dialami kelompok ternak Usaha Bersama Desa Ranotongkor Timur adalah sulit mengubah kebiasaan cara pemberian pakan oleh anggota. Cara pemberian pakan secara tradisional, yaitu penyedian pakan hanya mengandalkan rumput liar dan limbah tanaman jagung, menyebabkan pertumbuhan ternak agak lambat. Berat badan ternak sapi milik anggota kelompok lebih rendah dibanding dengan ternak sapi di daerah lain yang mengkonsumsi rumput berkualitas untuk umur dan jenis ternak sapi yang sama. Dalam menghadapi permasalahan tersebut, setiap anggota kelompok sesuai hasil kesepakatan kelompok menanam rumput di kebun masing-masing anggota. Tetapi, bagaimana manajemen hijauan makanan ternak belum diketahui oleh anggota kelompok. Berapa kebutuhan setiap ekor, cara menanam, kapan rumput dipotong belum diketahui anggota kelompok. Selain itu kurangnya pengetahuan anggota kelompok tentang penyediaan pakan (hijauan) secara kontinu dan berkualitas. Padahal jika anggota kelompok dapat menyediakan pakan (hijauan) secara kontinu dan berkualitas, maka produksi daging sapi akan meningkat.

Hasil penelitian menunjukkan bahwa kualitas hijauan yang diberikan pada ternak hampir tidak pernah diperhatikan oieh anggota kelompok. Padahal menurut Muslim dan Nurasa (2007), untuk menghasilkan produksi ternak sapi yang kompetitif sangat ditentukan oleh ketersediaan pakan hijauan. Penanaman hijauan dilakukan sebagai upaya memenuhi kebutuhan pakan ternak secara kualitas dan kuantitas serta untuk mengoptimalkan pemanfaatan lahan- lahan tidur. Introduksi rumput dwarf dilakukan dalam bentuk penyuluhan dan penanaman rumput.

\section{METODE PELAKSANAAN}

Pemberdayaan terhadap Kelompok Tani Usaha Bersama untuk menangani beberapa masalah prioritas dilakukan dengan 2 (dua) metode yaitu penyuluhan dan pelatihan. Penyuluhan dilakukan terhadap anggota Kelompok Usaha Bersama dengan tujuan mengubah perilaku sumberdaya anggota kelompok ke arah yang lebih baik. Setelah kegiatan penyuluhan anggota kelompok diberikan pelatihan. Pelatihan dimaksud adalah praktek penerapan teknologi. Penanaman rumput dilakukan pada lahan yang belum dimanfaatkan, meliputi tahapan: (1) pembersihan dan penyiapan lahan, (2) penyediaan bibit rumput dwarf, (3) penanaman, (4) perawatan, dan (5) pemanenan

\section{PEMBAHASAN}

\section{Konsep Pemberdayaan Kelompok Tani}

Pembangunan sektor pertanian penting dilakukan pada tataran regional Provinsi Sulawesi Utara, karena sektor pertanian menempati urutan pertama sebagai penyumbang dalam pembentukan Produk Domestik Regional Bruto (PDRB) Provinsi Sulawesi Utara dan penyerapan tenaga kerja. Tahun 2013 kontribusi sektor pertanian terhadap pembentukan PDRBterbesar mencapai 36 persen, diikuti sektor jasa sebesar 26 persen, serta sektor perdagangan, hotel dan restoran 
sebesar 18 persen. Sektor pertanian menyerap tenaga kerja sebesar 61 persen (BPS Sulut, 2014). Pentingnya sektor pertanian dalam perekonomian, disisi lain sektor pertanian menghadapi tantangan yang cukup besar mendorong Pemerintah sejak revolusi hijau memberikan perhatian yang besar dengan berbagai kebijakan pemberdayaan pertanian. Salah satu kebijakan untuk memberdayakan sektor pertanian yakni pemberdayaan kelompok tani.

Kelompok tani dibentuk untuk memecahkan permasalahan yang dihadapi petani yang tidak bisa diatasi secara individu. Syahyuti (2007) mengungkapkan bahwa pembentukan kelompok tani merupakan proses pewujudan pertanian yang terkonsolidasi (consolidated agriculture), sehingga bisa berproduksi secara optimal dan efisien. Rasionalisasi usahatani yang mengejar efisiensi dan nilai tambah ini akan mereduksi petani tradisional.

Diseminasi teknologi pertanian kepada petani peternak akan lebih efisien jika dilakukan pada kelompok, karena dapat menjangkau petani peternak yang lebih banyak dalam satuan waktu tertentu. Dalam hal ini kelompok dianggap sebagai organisasi yang efektif untuk memberdayakan petani peternak, meningkatkan produktivitas, pendapatan, dan kesejahteraan melalui program dari berbagai kebijakan pembangunan pertanian.

Beberapa manfaat adanya kelompok tani menurut Suwandi (2005) adalah: (1) kemudahan untuk mendapatkan sarana produksi, (2) kemudahan untuk pemasaran hasil, (3) meningkatkan keahlian dan keterampilan di bidang tehnis dan manajemen kelompok secara bersama-sama, (4) inisiatif dalam melaksanakan kegiatan pembangunan desa dan menciptakan kesadaran mobilisasi sumberdaya secara optimal, (5) saling mendukung sebagai anggota kelompok, (6) memudahkan komunikasi dan alih teknologi di bidang pertanian dan peternakan, dan (7) menciptakan hubungan dan jaringan dengan lembaga lain. Selain itu, penerapan teknologi akan lebih efektif apabila dilakukan untuk kelompok (Fagi et al., 2004; Fagi dan Kartaatmadja 2004, Elly et al., 2013).

\section{Sumber dan Jenis Hijauan Pakan di Desa Rano- tongkor Timur}

Pakan dapat digolongkan ke dalam sumber protein, sumber energi, dan sumber serat kasar. Hijauan pakan ternak (HPT) merupakan sumber serat kasar utama. Didalam sistem pemeliharaan ternak tradisional di Indonesia, HPT yang pada umumnya terdiri atas rumput dan leguminosa merupakan bagian terbesar dari seluruh pakan yang diberikan. Penanaman rumput dwarf di lahan anggota kelompok dipersiapkan untuk mengantisipasi kekurangan pakan baik jenis, kualitas dan kuantitasnya yang selalu menjadi masalah bagi petani di Desa Ranotongkor Timur. Pembuatan lahan percontohan diharapkan dapat mendorong anggota kelompok menanan jenis rumput ini sebagai upaya menjamin ketersediaan pakan sepanjang tahun karena selama ini petani hanya mengandalkan rumput liar dan limbah tanaman jagung sebagai pakan bagi ternak sapinya.

Hijauan pakan ternak dapat dibagi menjadi dua kategori. Pertama hijauan liar yaitu hijauan yang tidak sengaja ditanam dan tumbuh dengan sendirinya dan yang kedua yaitu hijauan introduksi atau hijauan yang sengaja ditanam dan dipelihara sebagaimana membudidayakan tanaman lainnya. Hijauan introduksi yang dibudidayakan hanya merupakan spesies rumput tertentu atau spesies leguminosa tertentu yang sengaja ditanam.

Hasil penelitian Elly et al. (2013) menunjukkan salah satu kendala pengembangan ternak sapi di Kabupaten Minahasa adalah kurang tersedianya rumput yang berkualitas. Sebagian besar ternak sapi hanya mengkonsumsi rumput lapang dan Iimbah pertanian. Pemeliharaan ternak di Desa Ranotongkor Timur, hampir seluruhnya mengandalkan hijauan makanan ternak yang tersedia di alam (padang penggembalaan), walaupun ada upaya untuk penanaman hijauan makanan ternak, namun dalam jumlah yang tidak memenuhi kebutuhan ternak (ditanam pada pekarangan atau sebagai pagar di depan halaman rumah).

Hasil penelitian tentang hijauan makanan ternak menunjukkan bahwa 100\% anggota kelompok belum bisa membedakan antara rumput dan leguminosa. Anggota kelompok juga tidak bisa membedakan mana rumput dan mana limbah pertanian. Padahal menurut Muslim dan Nurasa (2002) introduksi hijauan pakan ternak unggul telah lama dilakukan oleh pemerintah. Rumput yang biasa dijadikan pakan ternak seperti rumput alam, rumput gajah (Pennisetum purpureum), rumput setaria (Setaia sphacelata), rumput benggala, rumput raja (Pennisetum purpureophoides). Sedangkan jenis leguminosa seperti lamtoro (Leucaena leucocephala), kaliandra (Calliandra calothyrsus Meissn), gamal (Gliricidia sepium), dan turi (Sesbania grandiflora). Sisa hasil pertanian yang dapat dijadikan sumber hijauan pakan ternak seperti jerami padi, daun dan tongkol jagung, jerami kacang tanah.

Pakan hijauan yang diperlukan ternak sapi sebesar $10 \%$ dari berat badan. Berikut ini perbandingan penerimaan yang diperoleh peternak bila menggunakan rumput lapangan, rumput berkualitas, dan rumput berkualitas dengan introduksi teknologi : (a) produksi daging yang dihasilkan apabila ternak sapi makan rumput lapangan $=0.3 \mathrm{~kg} / \mathrm{hari}$, apabila 
harga daging sapi Rp 90 000/kg berarti tambahan penerimaan dalam 6 bulan sebesar Rp 4860 ooo, (b) produksi daging yang dihasilkan apabila ternak sapi makan rumput berkualitas $=0.5 \mathrm{~kg} / \mathrm{hari}$, apabila harga daging sapi $\mathrm{Rp} 90$ 000/kg berarti tambahan penerimaan dalam 6 bulan sebesar Rp 8100 ooo, dan (c) produksi daging yang dihasilkan apabila ternak sapi makan rumput berkualitas (dwarf) 0.8 $\mathrm{kg} / \mathrm{hari}$, apabila harga daging sapi $\mathrm{Rp} 90 \mathrm{000} / \mathrm{kg}$ berarti tambahan penerimaan dalam 6 bulan sebesar Rp 12960 ooo. Berdasarkan perhitungan ini dapat diketahui bahwa pemberian rumput berkualitas (dwarf) menghasilkan produksi dan penerimaan tertinggi dibandingkan pemberian rumput lapangan dan pemberian rumput berkualitas tanpa teknologi.

\section{Introduksi Rumput Gajah Dwarf pada Kelom- pok Usaha Bersama Desa Ranotongkor Timur}

Hijauan pakan merupakan salah satu faktor penentu dalam pengembangan usaha peternakan khususnya untuk ternak ruminansia. Ketersediaan hijauan pakan yang tidak memadai baik kuantitas maupun kualitasnya, menjadi salah satu kendala dalam pengembangan usaha peternakan. Sehingga diperlukan upaya untuk menyediakan hijauan pakan yang cukup baik dan bisa terjamin kontinuitasnya. Salah satu upaya yang harus dilakukan adalah memelihara, meningkatkan produksi, serta pertumbuhan dan perkembangan hijauan pakan. Dari sekian banyak jenis rumput gajah yang ada di Indonesia yang belum banyak dikenal adalah rumput gajah dwarf (Pennisetum purpureum $c v$. Mott). Rumput dwarf merupakan salah satu rumput unggul yang berasal dari Philipina dengan kandungan nutrisi dan tingkat produktivitas yang tinggi. Menghasilkan banyak anakan, mempunyai akar kuat, batang yang tidak keras dan mempunyai ruas-ruas daun yang banyak serta struktur daun yang muda sehingga sangat disukai ternak (Lasamadi et al. (2013). Syarifuddin (2006), Polakitan dan Kairupan (2015) menyatakan kualitas rumput dwarf lebih tinggi pada berbagai tingkat usia dibandingkan jenis rumput tropis lainnya disebabkan perbandingan rasio daun yang tinggi dibandingkan batang, tahan kekeringan, propagasi melalui metoda vegetatif, dapat tumbuh diberbagai tempat, tahan lindungan, respon terhadap pemupukan, serta memiliki palatabilitas yang tinggi bagi ternak ruminansia. Selain itu rumput ini memiliki daya cerna nitrogen $(\mathrm{N})$ dan bahan kering tertinggi dibandingkan rumput-rumput tropis lainnya.

Rumput dwarf tumbuh merumpun dengan perakaran serabut yang kompak, dan terus menghasilkan anakan apabila dipangkas secara teratur. Morfologi rumput gajah mini yang rimbun, dapat mencapai tinggi lebih dari 1 meter sehingga

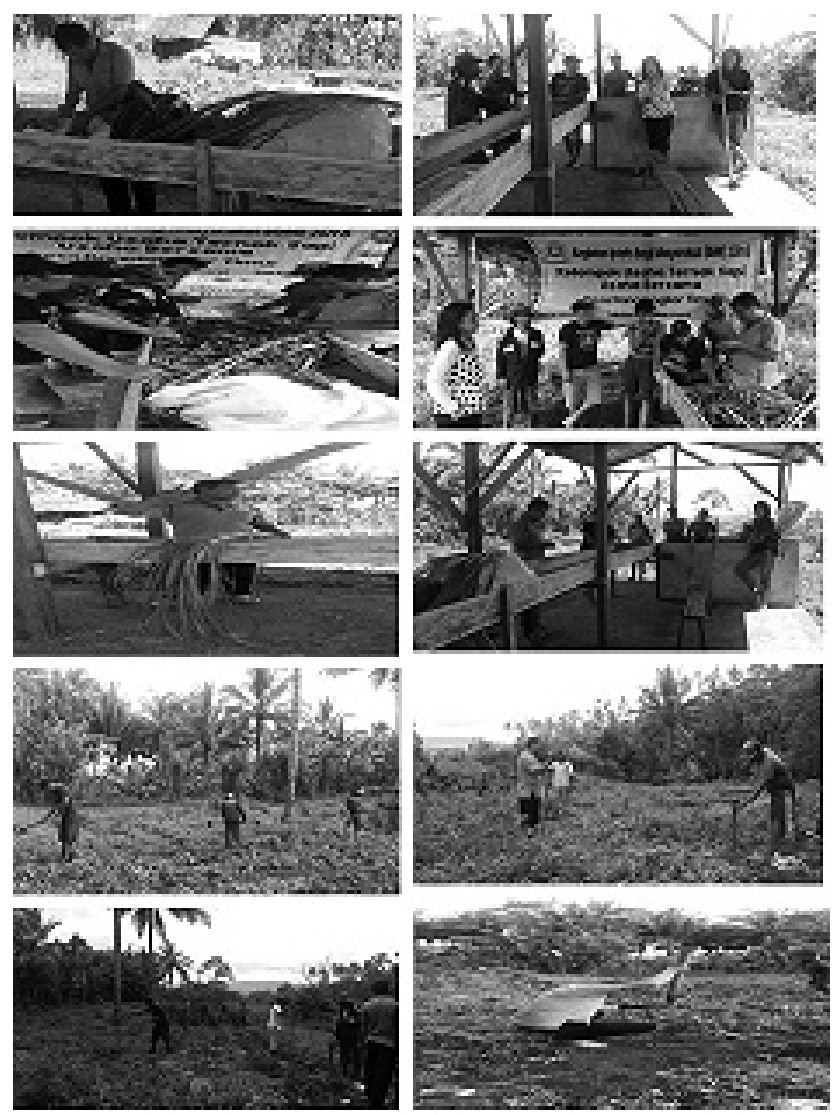

Gambar 1. Kegiatan Penanaman Rumput Dwarf Kelompok Usaha Bersama Desa Ranotongkor Timur

dapat berperan sebagai penangkal angin (wind break) terhadap tanaman utama (Syarifuddin 2006).

Pemberdayaan Kelompok Usaha Bersama melalui penanaman rumput dwarf dilakukan melalui kegiatan penyuluhan dan pelatihan. Penyuluhan menyandarkan programnya pada kebutuhan petani peternak dan proses pendidikan untuk orang dewasa yang bersifat non formal. Tujuannya untuk mengajar petani peternak, mengajar petani peternak untuk menggunakan sumberdaya alamnya dengan bijaksana, meningkatkan kesejahteraan dengan usahanya sendiri, dan penyuluh bekerja sama dengan organisasi lainnya untuk mengembangkan individu, kelompok dan bangsa. Materi penyuluhan menyangkut manajemen hijauan pakan, kualitas nutrisi, dan teknik pembudidayaan rumput dwarf.

Kegiatan selanjutnya berupa pelatihan penanaman rumput dilakukan pada lahan yang belum dimanfaatkan, meliputi tahapan: (1) pembersihan dan penyiapan lahan, (2) penyediaan bibit rumput dwarf, dan (3) penanaman. Pemberdayaan Kelompok Usaha Bersama dapat dilihat pada Gambar 1.

Pembudidayaan dilakukan dengan potongan batang (stek) atau sobekan rumpun (pols)

sebagai bibit. Bahan stek berasal dari batang yang sehat dan tua, dengan panjang stek $20-25 \mathrm{~cm}$ ( 2 - 3 ruas atau paling sedikit 2 buku atau mata). 
Waktu yang terbaik untuk memotong tanaman yang akan dibuat silase adalah pada fase vegetatif, sebelum pembentukan bunga (Reksohadiprodjo 1994). Prospek rumput gajah mini cukup baik bila dilakukan pemupukan yang baik pula. Dengan memanen pada pertumbuhan yang masih muda atau dengan menggunakan kultivar yang baik akan mencapai nilai pakan yang tinggi, dan dapat diusahakan secara mekanis atau juga untuk pertanian/peternakan skala kecil (Syarifuddin 2006).

Penerapan Iptek ini diharapkan akan mampu memberikan solusi untuk memenuhi kebutuhan pakan untuk ternak sapi. Kalau mitra mampu menjamin ketersediaan pakan bagi ternaknya, maka petani peternak mitra akan mampu memproduksi ternak yang lebih berkualitas dan mampu meningkatkan kapasitas produksi.

\section{SIMPULAN}

Dari uraian di atas dapat disimpulkan bahwa introduksi rumput dwarf pada Kelompok Usaha bersama dapat menambah dan memperkaya jenis hijauan pakan ternak yang mempunyai nilai nutrisi tinggi dalam upaya perbaikan kualitas pakan dan peningkatan produktivitas dan produksi ternak sapi di Desa Ranotongkor Timur.

\section{UCAPAN TERIMA KASIH}

Terima kasih kepada DP2M DIKTI yang telah memberikan kesempatan kepada penulis dan mendanai kegiatan ini melalui IbM tahun 2016.

\section{REFERENSI}

BPS Sulut. 2014. Kecamatan Tombariri Timur dalam Angka. Badan Pusat Statistik Provinsi Sulawesi Utara, Manado.

Elly F H, M A V Manese, D Polakitan. 2013. Pemberdayaan Kelompok Tani Ternak Sapi melalui Pengembangan Hijauan di Sulawesi Utara. Pastura 2(2):61-65.

Fagi A M, A Djajanegara, K Kariyasa dan I G Ismail. 2004. Keragaman Inovasi Kelembagaan dan
Sistem Usahatani Tanaman - Ternak di Beberapa Sentra. Prosiding Seminar. Sistem Kelembagaan Usahatani Tanaman-Ternak. Badan Peneiitian dan Pengembangan Pertanian. Departemen Pertanian, Jakarta Selatan.

Fagi A M dan S Kartaatmadja. 2004. Dinamika Kelembagaan Sistem Usahatani Tanaman-Ternak dan Diseminasi Tehnologi. Prosiding Seminar. Sistem Kelembagaan Usahatani TanamanTernak. Badan Penelitian dan Pengembangan Pertanian. Deparlemen Pertanian, Jakarta Selatan.

Lasamadi RD, S Malalantang, S Rustandi dan S D Anis. 2013. Pertumbuhan dan perkembangan rumput gajah dwarf (Pennisetum purpureum cv. Mott) yang diberi pupuk organik hasil fermentasi EM4. Jurnal Zootek 32 (5): 158-171.

Muslim C dan T Nurasa. 2007. Kebijakan Pengembangan Ternak sapi Potong di Wilayah Sentra Produksi Berbasis Tanaman Pangan (SIPT) di Indonesia. Jurnal Soca. Vol 8 (3). p: 250-255.

Nuryanti, S., dan D. K. S. Swastika. 2011. Peran Kelompok Tani dalam Penerapan Teknologi Pertanian. Forum Penelitian Agro Ekonomi 29(2): 115-128.

Polakitan dan Kairupan 2015. Pertumbuhan dan Produktivitas Rumput Gajah Dwarf (Pennisetum purpureum cv. Mott). Makalah disampaikan pada Seminar Regional Inovasi Teknologi Pertanian, Mendukung Program Pembangunan Pertanian Provinsi Sulawesi Utara. BPTP Sulut, Manado.

Reksohadiprodjo, S. 1994. Produksi Tanaman Hijauan Makanan Ternak Tropik. BPFE. University Gadjah Mada, Yogyakarta.

Syahyuti. 2007. Kebijakan Pengembangan Gabungan Kelompok Tani (Gapoktan) sebagai Kelembagaan Ekonomi di Perdesaan. Analisis Kebijakan Pertanian Vol. 5 (1), Maret 2007: 15-35. Pusat Analisis Sosek dan Kebijakan Pertanian. Bogor.

Syarifuddin N A. 2006. Nilai Gizi Rumput Gajah Sebelum dan Setelah Enzilase pada Berbagai Umur Pemotongan. Produksi Ternak Fakultas Pertanian UNLAM. Lampung. 